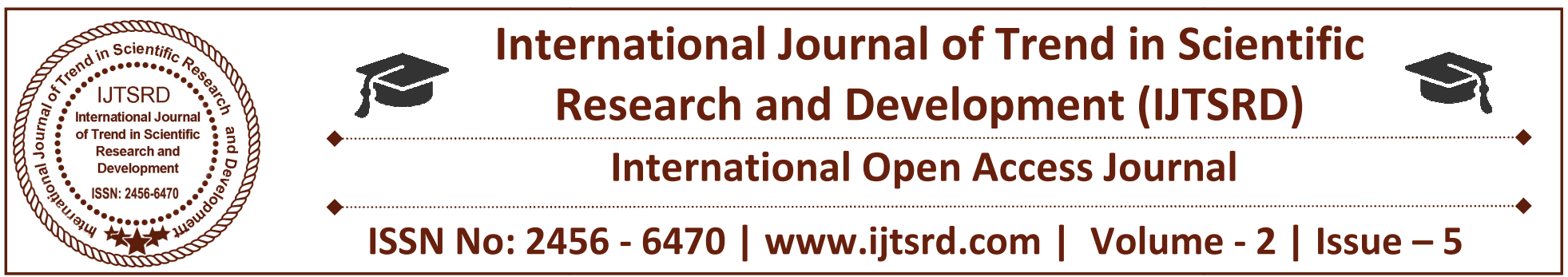

\title{
Impact of NPAs on the Performance of UCO Bank: A Study
}

\author{
Sanjay Dawn ${ }^{1}$, Dr. Subhas Chandra Sarkar ${ }^{2}$ \\ ${ }^{1}$ Research Scholar, ${ }^{2}$ Professor \\ Department of Commerce, University of Kalyani, West Bengal, India
}

\begin{abstract}
Indian banking sector has been facing terrible problem due to the deterioration quality of assets which is increasing gradually. The growth of NPA has a direct impact on the overall performance of the bank. The problems of NPAs not only affecting the bank but also affect the entire economy. The present study is analytical in nature and completely based on secondary data analysed by using accounting and statistical tools. The UCO Bank was established before the independence and worked successfully, but now facing various problems due to NPAs. In this above background the present study assess the financial strength, quality of loan assets and NPA management and also discussed the impact of NPAs on the performance of UCO Bank as well as the recovery performance of NPAs.
\end{abstract}

KEYWORD: Non-performing assets, RBI, Commercial Bank, Economic development

\section{INTRODUCTION}

Strong banking system of a country works as the main driving for the economy and plays an important role in the economic development of the country. Transparent and effective banking system makes the healthy and strong economy of the country. But now a day's the bank's health and performance diminishing due to increase in non-performing assets(NPA) of the bank which causes the country's economy to deteriorate. UCO Bank, previously known as United Commercial Bank, emerged successful in early stage of their incorporation and there are a significant presence of UCO Bank not only in the financial markets of India, it is also outside of India. But in this decade UCO Bank faced some unwanted difficulties which affect the performance of the bank. The main reason for the bad performance of the UCO Bank is that most of the assets become non-performing and increased year after year. So NPA is the core financial problem for the bank and considered to be a most important parameter to evaluate its impact on the performance of the bank.

\section{LITERATURE REVIEW}

Bansal, A. (2012), in his research paper discussed the concept and recent trends of NPAs of public sector banks. He also analyse the impact of NPAs and evaluate the reasons for NPAs and suggest how to reduced NPAs and improve assets quality of the bank.

Garg, A. (2015), in his paper attempts a comparative assessment of non-performing assets in public sector bank, private sector bank and foreign bank and suggest that to improve non-interest income public sector bank must find appropriate means, as interest income affect the net profit due to rise in NPA.

Singh, V.R. (2016), in his article highlights the status and trend of NPAs in Indian schedule commercial bank, the factors contributing to NPAs, reasons for high impact of NPAs and how to recovery of NPAs through various channels. He observed that extent of NPA is comparatively very high in public sectors banks, although government have been taken various step to reduced the NPAs.

Sharifi, O. and Akter, J. (2016), in their paper highlights the trends, status and impact of NPAs on profitability of Public Sector Banks during the period of 7 years (2009-2015) and found that the impact of NPA negatively on financial performance of public sector banks under the study period. 
Chalam, G.V. (2017), in his paper attempts to study the trends of NPAs in Indian Banking sector, specifically sector wise, and identify the causes and consequences of NPAs and suggest establishing a sound control and feedback mechanism on banking operations.

\section{OBJECTIVES OF THE STUDY}

The main objectives of this study are:

$>$ To analysis the NPAs of UCO Bank

$>$ To evaluate the impact on NPAs on the performance of UCO Bank

$>$ To evaluate the recovery performance of NPAs of UCO Bank

\section{RESEARCH METHODOLOGY}

Data Collection: The data has been collected from secondary source which includes RBI reports, various articles, journals and research papers.

Study Period: The present study has been covered a period of five consecutive financial years from 201314 to $2017-18$.

Tools and Techniques: The data are analyzed by different accounting and statistical tools and conceptual understanding.

\section{CONCEPT OF NPAS}

The concept of NPAs developed from Reserve Bank of India (RBI) prudential norms which was recommended by the Narsimham Committe, applicable from 1992-93 in Indian Commercial Banks. As per the prudential norms bank assets are classified into two broad categories viz. Performing Assets and Non-performing Assets. Performing Assets are those assets which generate interest income regularly and customers paid the instalment of principal and interest amount within the due date. On the contrary, non-performing assets are those assets, where customers are not able to pay the interest or principal or both within the due date. As per RBI guidelines, assets of bank classified into four categories i.e. Standard assets, Sub-standard assets, Doubtful Assets and Loss Assets of which Standard Assets considered as Performing Assets and the sum of last three are considered Non-performing Assets. Further, NPAs is also classified two categories viz. Gross NPA and Net NPA.

\section{RATIO ANALYSIS AND THE NPA MANAGEMENT}

To assess the financial strength, quality of loan assets and NPA management, it is very important to analyze different parameters with respect to NPA. Here an attempt has been made to assess the position of NPA of UCO Bank with the help of ratio analysis by using important ratios as follows:

Table 1: Ratios relating to NPAs

\begin{tabular}{|c|c|c|c|c|c|}
\hline Year & $\begin{array}{c}\text { Gross NPA } \\
\text { Ratio (\%) }\end{array}$ & $\begin{array}{c}\text { Net NPA } \\
\text { Ratio }(\%)\end{array}$ & $\begin{array}{c}\text { Sub-Standard Assets } \\
\text { Ratio }(\%)\end{array}$ & $\begin{array}{c}\text { Doubtful Assets } \\
\text { Ratio (\%) }\end{array}$ & $\begin{array}{c}\text { Loss Assets } \\
\text { Ratio }(\%)\end{array}$ \\
\hline $2013-14$ & 4.32 & 2.38 & 36.63 & 56.70 & 6.68 \\
\hline $2014-15$ & 6.76 & 4.30 & 51.24 & 47.74 & 1.07 \\
\hline $2015-16$ & 15.43 & 9.09 & 28.54 & 67.22 & 4.23 \\
\hline $2016-17$ & 17.12 & 8.94 & 22.21 & 72.69 & 5.09 \\
\hline $2017-18$ & 24.64 & 13.10 & 19.99 & 71.75 & 8.25 \\
\hline Average & 13.65 & 7.562 & 31.72 & 63.22 & 5.06 \\
\hline
\end{tabular}

Source: Compiled from Annual Reports of the UCO Bank.

\section{Gross NPA Ratio}

Gross NPA Ratio $=($ Gross NPA/Gross Advance $) \times$ 100

Gross NPA indicates the quality of credit portfolio of the bank. High Gross NPA Ratio indicates the low quality credit portfolio. Table 1 shows that, on an average, Gross NPA arrives at $13.65 \%$ during the period of study and it gives a continuous upward trend. It is observed that the management of UCO Bank are not paying adequate attention to take care of and following ideal norms of granting advance, so that recovery is not satisfactory which leads to higher Gross NPA Ratio.

\section{Net NPA Ratio}

Net NPA Ratio $=($ Gross NPA - Provisions $) /($ Gross Advances - Provisions) $\times 100$

Net NPA indicates the risk of existing loan of the bank. High Net NPA Ratio indicates the existence of highly risky loans of the bank for which no adequate provision has been made. From the Table 1 it is noticed that Net NPA Ratio is $2.38 \%$ in $2013-14$ and 
it is significantly increased every year and in 2017-18 finally reached to $13.10 \%$ which is significantly higher than the average Gross NPA Ratio (7.562\%). The UCO Bank had failed to make sufficient provision against NPA which indicates unsatisfactory position.

\section{Sub-standard Assets Ratio}

Sub-standard Assets Ratio $=$ (Total Sub-standard assets/Gross NPA) $\times 100$

Sub-standard Assets Ratio indicates the scope for improvement in NPA of the bank. High Sub-standard Assets Ratio indicates is the better position of recovering the advances. From the Table 1 it is observed that Sub-standard Assets Ratio, which is $36.63 \%$ in 2013-14 significantly decreasing every year and finally reached to $19.99 \%$ in $2017-18$ which is much lower than the average Sub-standard Assets Ratio $(31.722 \%)$ due to the higher percentage of doubtful assets over the Sub-standard Assets.

\section{Doubtful Assets ratio}

Doubtful Assets Ratio $=($ Total Doubtful Assets/Gross NPA) $\times 100$

Doubtful Assets Ratio indicates the performance of management in respect of NPA of the bank. High Doubtful Assets Ratio indicates the management of NPA in the bank is appear to be poor and there is more scope for reducing NPAs by adopting softening attitude towards customers. From the Table 1 it is understand that the ratio had been not satisfactory except for two years i.e. 2013-14 (56.705) and 201415 (47.745).

\section{Loss Assets Ratio}

Loss Assets Ratio $=($ Total Loss Assets $/$ Gross NPA $) \times$ 100

Loss Assets Ratio indicates the higher losses or high erosion of securities of the bank. High Loss Assets Ratio indicates higher losses, so this ratio would be as low as possible. From the above Table 1 it is understand that Loss Assets Ratio had been higher than average ratio for two year i.e. 2013-14 and 201718 , otherwise it is low.

\section{ANALYSIS OF THE IMPACT OF NPA ON THE PERFORMANCE OF UCO BANK}

To analyze the impact of NPA on the performance of the UCO Bank in terms of Profitability, Liquidity and Involvement of Management (IM) under this study from 2013-14 to 2017-18, a linear Multiple Regression Model has been used. For analysis, we have taken gross NPA as independent variables; on the other hand, bank's performance indicators such as Profitability, Liquidity and Involvement of Management (IM) are taken as dependent variables.

To investigate the dependence between two or more variables at the same time, compute a correlation matrix.

Table 2: Correlation Matrix among Dependent and Independent variables

\begin{tabular}{|c|c|c|c|c|c|}
\hline & & ROA & Liquidity & IMI & NPA \\
\hline \multirow{3}{*}{ ROA } & Pearson Correlation & 1.000 & -0.975 & -0.884 & -0.983 \\
\hline & Sig. (1-tailed) & 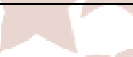 & 0.002 & 0.023 & 0.001 \\
\hline & $\mathrm{N}-\mathrm{C}$ & 5 & 5 & 5 & 5 \\
\hline \multirow{3}{*}{ Liquidity } & Pearson Correlation & -0.975 & 1.000 & 0.869 & 0.972 \\
\hline & Sig. (1-tailed) & 0.002 & & 0.028 & 0.003 \\
\hline & $\mathrm{N}$ & 5 & 5 & 5 & 5 \\
\hline \multirow{3}{*}{$\mathrm{IM}$} & Pearson Correlation & -0.884 & 0.869 & 1.000 & 0.938 \\
\hline & Sig. (1-tailed) & 0.023 & 0.028 & & 0.009 \\
\hline & $\mathrm{N}$ & 5 & 5 & 5 & 5 \\
\hline \multirow{3}{*}{ NPA } & Pearson Correlation & -0.983 & 0.972 & 0.938 & 1.000 \\
\hline & Sig. (1-tailed) & 0.001 & 0.003 & 0.009 & \\
\hline & $\mathrm{N}$ & 5 & 5 & 5 & 5 \\
\hline
\end{tabular}

Source: Computation through SPSS 
The above Table 2 shows that NPA is negatively correlated with ROA and positively correlated with

Liquidity and IM which is significant for this study.

The simple linear regression model has been sketchy to investigate the impact of NPA on the performance of UCO Bank, which as follows:

$1^{\text {st }}$ Model: $\quad \mathrm{ROA}=\alpha+\beta \mathrm{NPA}+€$

$2^{\text {nd }}$ Model: Liquidity $=\alpha+\beta$ NPA $+€$

$3^{\text {rd }}$ Model: $\mathrm{IM}=\alpha+\beta \mathrm{NPA}+€$

Where, ROA (Return on Assets) $=$ (Net Profit or Loss) / (Total assets)

Liquidity $=($ Total Assets $/$ Total Loans $)$
IM (Involvement of Management) = (Operating

Expenses/Total Revenue)

$\alpha=$ Constant,

$\beta=$ Regression Coefficients and

$€=$ Error Term

\section{Regression Analysis based on $1^{\text {st }}$ Model:}

To observe the significant relation between NPA and Profitability (ROA) of UCO Bank we have taken the hypothesis

$1^{\text {st }}$ Hypothesis:

$\mathrm{H}_{0}=$ When NPA decreases, profitability (ROA) decreases

$\mathrm{H}_{1}=$ When NPA increases, profitability (ROA) decreases

Table 3: Regression Coefficients of UCO Bank (Dependent variable: ROA)

\begin{tabular}{|c|c|c|c|c|c|}
\hline \multirow{2}{*}{ Model 1 } & \multicolumn{2}{|c|}{ Unstandardized Coefficient } & Standardized Coefficient & \multirow{2}{*}{$\mathbf{t}$} & \multirow{2}{*}{ Sig. } \\
\cline { 2 - 3 } \cline { 5 - 6 } & $\mathrm{B}$ & Std. Error & Beta & 5.904 & 0.010 \\
\hline Constant & 1.397 & 0.237 & -0.987 & -9.164 & 0.003 \\
\hline NPA & -0.256 & 0.028 & Source: Computation through SPSS &
\end{tabular}

Source: Computation through SPSS

From the Table 3, we get the regression equation is ROA $=1.397-0.256$ NPA. Table 3 shows that profitability is linked negatively with NPA. When NPA is increased by one unit, ROA is decreased negatively by 0.256 units that support the economic theory because ROA and NPA must be inversely related. The result shows that for the independent variable NPA, the probability of t statistic (-) 9.164 for the $b$ coefficient is 0.003 which is less than the significant level of 0.05 . So we reject the null hypothesis that, there is no significant impact of NPA on ROA.
Regression Analysis based on $2^{\text {nd }}$ Model:

To observe the significant relation between NPA and Liquidity of UCO Bank we have taken the hypothesis

$2^{\text {nd }}$ Hypothesis:

$\mathrm{H}_{0}=$ There is no significant negative relationship between NPA and Liquidity

$\mathrm{H}_{1}=$ There is significant negative relationship between NPA and Liquidity

Table 4: Regression Coefficients of UCO Bank (Dependent variable: Liquidity)

\begin{tabular}{|c|c|c|c|c|c|}
\hline \multirow{2}{*}{ Model 2 } & \multicolumn{2}{|c|}{ Unstandardized Coefficient } & Standardized Coefficient & \multirow{2}{*}{$\mathbf{t}$} & \multirow{2}{*}{ Sig. } \\
\cline { 2 - 3 } \cline { 5 - 6 } & $\mathrm{B}$ & Std. Error & Beta & 30.838 & 0.000 \\
\hline Constant & 1.515 & 0.049 & 0.972 & 7.180 & 0.006 \\
\hline NPA & 0.042 & 0.006 & & 0.972 &
\end{tabular}

Source: Computation through SPSS

From the Table 4, we get the regression equation is ROA $=1.515+0.042$ NPA. Table 4 shows that profitability is linked positively with NPA. When NPA is increased by one unit, ROA is increase positively by 0.042 units that does not support the economic theory because Liquidity and NPA must be inversely related. The result shows that for the independent variable NPA, the liquidity of $t$ statistic
(7.180) for the b coefficient is 0.006 which is less than the significant level of 0.05 . So we reject the null hypothesis that there is no significant impact of NPA on Liquidity.

\section{Regression Analysis based on $3^{\text {rd }}$ Model:}

To observe the significant relation between NPA and IM of UCO Bank we have taken the hypothesis 
International Journal of Trend in Scientific Research and Development (IJTSRD) ISSN: 2456-6470

$3^{\text {rd }}$ Hypothesis:

$\mathrm{H}_{0}=$ There is no positive relationship between NPA $\mathrm{H}_{1}=$ There is a positive relationship between NPA and IM and IM

Table 5: Regression Coefficients of UCO Bank (Dependent variable: IM)

\begin{tabular}{|c|c|c|c|c|c|}
\hline \multirow{2}{*}{ Model 3 } & \multicolumn{2}{|c|}{ Unstandardized Coefficient } & Standardized Coefficient & \multirow{2}{*}{$\mathrm{t}$} & \multirow{2}{*}{ Sig. } \\
\cline { 2 - 3 } & $\mathrm{B}$ & Std. Error & \multirow{2}{*}{ Beta } & & \\
\hline Constant & 0.097 & 0.012 & 0.152 & 0.004 \\
\hline NPA & 0.007 & 0.001 & 0.938 & 4.673 & 0.019 \\
\hline
\end{tabular}

Source: Computation through SPSS

From the Table 5, we get the regression equation is ROA $=0.097+0.007$ NPA. Table 2 shows that profitability is linked positively with NPA. When NPA is increased by one unit, IM is increased positively by 0.007 units that support the economic theory because IM and NPA must be directly related. The result shows that for the independent variable NPA, the probability of $t$ statistic (4.673) for the $b$ coefficient is 0.019 which is less than the significant level of 0.05 . So we reject the null hypothesis. Hence we conclude that there is significant impact of NPA on IM.

\section{RECOVERY PERFORMANCE}

Recovery management is the key factor to stability of the banking sector in containment of non-performing assets considering the overall difficulties. The main objectives of recovery management are NPA reduction, Deposit growth and Advance growth. For improving recovery in decreed account, the bank adopted several RBIs mechanism for recovery of NPAs such as Modified Compromises Settlement Scheme, SARFAESI Act, DRTs, Lok Adalats, Country wise mega recovery camps etc. The details of Cash Recovery and Up gradation shown below:

Table: Cash Recovery and Up gradation (Rs. in Crore)

\begin{tabular}{|c|c|c|c|c|}
\hline Year & Cash Recovery & Up gradation & Total & $\begin{array}{c}\text { Recovery in Loss Assets } \\
\text { (ML \& Tech Write-off a/c) }\end{array}$ \\
\hline 2014 & 2015 & 1032 & 3047 & 295 \\
\hline 2015 & 1629 & $877 / 6$ & 2506 & 189 \\
\hline 2016 & 1368.58 & 1357.86 & 2726.44 & 131.01 \\
\hline 2017 & 2038.66 & 4300.45 & 6339.11 & 139.81 \\
\hline 2018 & 1680.04 & 2610.08 & 4290.12 & 181.56 \\
\hline
\end{tabular}

Source: Compiled from Annual Reports of the UCO Bank.

The total of cash recovery and up gradation for the year 2018 is Rs. 4290.12 Crore as against Rs. 6339.11 Crore for the year 2017. It is too lower than the previous year. The recovery of written off accounts is Rs. 181.56 Crore for the year 2018 comparatively high to Rs. 139.81 Crore for the year 2017 and last three years it is increasing trend.

\section{CONCLUSION}

The Non-performing assets not only created big problem for Indian banking sector but also the economy too. This study shows that the money blocked in NPAs of UCO Bank is very high and its affects the profitability, liquidity and involvement of management adversely. The bank should take timely action against the deterioration of performing assets. The performance of recovery is also not satisfactory. The bank management should speed up the recovery and up gradation process and make efforts to manage and reduce NPA. The government should also take some initiative and make more provision against loan defaulters for faster settlement of pending cases.

\section{REFERENCE}

\section{Journals}

1. Bansal, A. "A Study of recent trends in Risk Management of Non-performing Assets (NPAs) By Public Sector Banks in India", Journal of Information and Operations Management, Vol. 3, Issue 1, pp.50-56, 2012.

2. Garg, A. "Statistical Investigation and Comparative Assessment of the Non-performing assets of Indian Commercial Banks, IJMBR, Vol. 5, Issue 4, pp.287-302, 2015.

3. Singh, V. R. "A Study of Non-performing Assets of Commercial Banks and it's Recovery in India”, 
Annual Research Journal of SCMS, Vol. 4, March 2016, pp. 109-125, 2016.

4. Sharifi, O. and Akter, J. "Effect of Non Performing Assets on the Profitability of Public Sector Banks of India", IJEMR, Vol. 6, Issue 5, pp.383-388, 2016

5. Chalam, G.V. "Mounting of Non-Performing Assets and its Impact on the Performance of
Indian Banking Sector", Management Today, Vol. 7, No. 2, pp.98-107, 2017.

\section{Websites}

1. http://www.rbi.org.in

2. http://www.dbie.rbi.org.in

3. http://www.ucobank.com

4. http://www.wikipedia.org

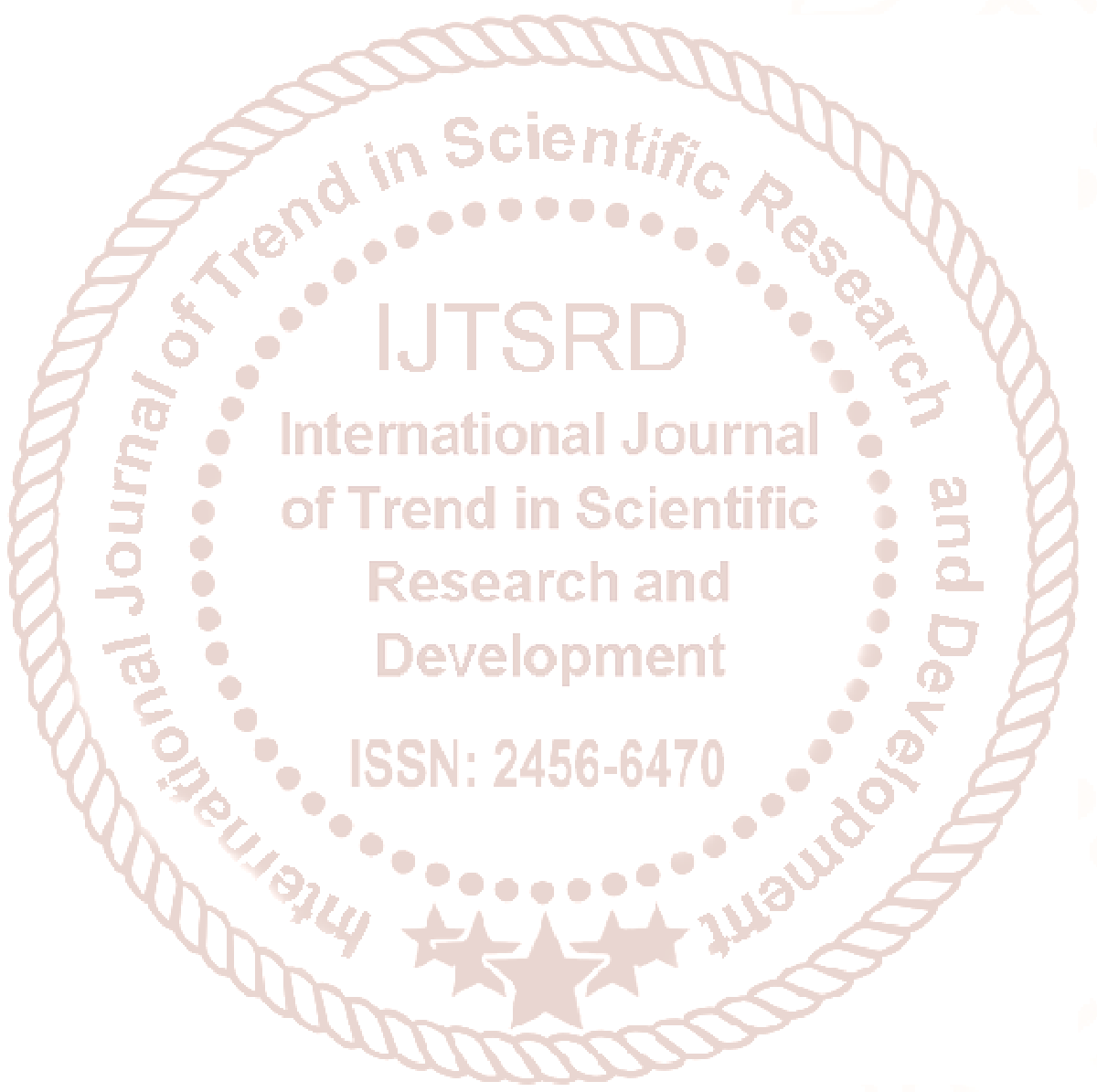

